\title{
Time-dependent post mortem changes in the composition of intestinal bacteria using real-time quantitative PCR
}

Sari Tuomisto ${ }^{1,2^{*}}$, Pekka J Karhunen ${ }^{1,2}$ and Tanja Pessi $i^{1,2}$

\begin{abstract}
Post mortem or even normal changes during life occurring in major gut bacterial populations are not known. We investigated Bacteroides sp., Bifidobacterium sp., Clostridium leptum, Clostridium coccoides, Streptococcus sp., Lactobacillus sp. and Enterobacteriacaea ratios in 7 fecal samples from healthy volunteers and in 61 autopsies rectum and cecum samples and studied the effect of post mortem time using quantitative real-time PCR. Bacterial ratios in stool samples from volunteers and rectum samples from autopsy cases were similar and did not change significantly up to 5 days post mortem. In cecum, significant post mortem time-dependent differences were observed in ratios of Bacteroides sp. $(p=0.014)$ and Lactobacillus sp. $(p=0.024)$. Our results showed that ratios of Bacteroides sp., Bifidobacterium sp., Clostridium leptum, Clostridium coccoides, Streptococcus sp., Lactobacillus sp. and Enterobacteriacaea can be investigated in autopsy rectum samples up to 5 days after death.
\end{abstract}

Keywords: Forensic science, Post mortem microbiology, Fecal sample, Real-time quantitative polymerase chain reaction, Bacterial relative amount, Time-dependent changes

\section{Background}

Basic knowledge on the composition of intestinal bacterial populations and changes occurring after death is lacking. Even the normal composition of intestinal microbiota in life is not fully known [1]. Only one study exists in which intestinal bacterial populations have been studied in three elderly women after death using PCR and sequencing [2].

Resident micro-organisms living in the intestinal tract influence host's normal well-being and physiology including gut metabolism and the regulation of epithelial cell growth [3]. Intestinal microbiota functions as a physical barrier against invading pathogens. It has been suggested that gut microbiota may have a role on the development of diseases, e.g. alcoholic liver cirrhosis [4] and atherosclerosis [5]. Detailed bacterial population studies on the intestinal tract have mostly concentrated on fecal samples because they are easy to collect. Intestinal microbiota consists of a large and diverse community containing hundreds of commensal bacterial species [6]. From sequencing

\footnotetext{
* Correspondence: Sari.Tuomisto@uta.fi

${ }^{1}$ Department of Forensic Medicine, School of Medicine, University of

Tampere, Medisiinarinkatu 3, Tampere 33014, Finland

${ }^{2}$ Fimlab Ltd, Pirkanmaa Hospital District, Biokatu 4, Tampere 33520, Finland
}

libraries of 16S rRNA genes Durban et al. found that two dominant phyla, Firmicutes and Bacteroidetes accounted for nearly $85 \%$ of all sequences in stool samples [7]. Compared to these two major phyla, Bifidobacterium genus is present in eight to ten-fold lower numbers [8]. Although Bacteroides sp., Bifidobacterium sp. and bacteria belonging to the Clostridium coccoides-group (cluster XIVa) and Clostridium leptum-group (cluster IV) dominate in colon $[9,10]$ there is substantial inter- and intra-individual variation in species composition and distribution $[7,11]$.

This study aimed to investigate ratios of major intestinal bacterial populations in healthy volunteers and in rectum and cecum autopsy samples. Post mortem timedependent changes were studied in order to see whether autopsy samples can be used for basic research concerning lifetime. Six species: Bacteroides sp. (phylum Bacteroidetes), Clostridium sp. (Firmicutes), Streptococcus sp. (Firmicutes), Lactobacillus sp. (Firmicutes), Bifidobacterium sp. (Actinobacteria) and Enterobactericaea (Proteobacteria) were chosen since they represent the major intestinal bacterial phyla [12].

\section{() Biomed Central}

(c) 2013 Tuomisto et al.; licensee BioMed Central Ltd. This is an open access article distributed under the terms of the Creative Commons Attribution License (http://creativecommons.org/licenses/by/2.0), which permits unrestricted use, distribution, and reproduction in any medium, provided the original work is properly cited. 
Table 1 Demographic characteristics of the study subjects divided by post mortem time

\begin{tabular}{|c|c|c|c|c|c|c|c|}
\hline \multirow[b]{3}{*}{ Autopsy cases: } & \multirow[b]{2}{*}{$\mathbf{N}$} & \multirow[b]{2}{*}{ PM mean } & \multirow[b]{2}{*}{$\begin{array}{l}\text { Age mean } \\
\text { (range) }\end{array}$} & \multirow[b]{2}{*}{ BMI mean (range) } & \multicolumn{3}{|c|}{ Basic cause of death } \\
\hline & & & & & $\begin{array}{c}\text { Heart } \\
\text { diseases \% }\end{array}$ & $\begin{array}{c}\text { Other } \\
\text { diseases \% }\end{array}$ & $\begin{array}{l}\text { Violent deaths (suicide, } \\
\text { accident, poisoning) \% }\end{array}$ \\
\hline & & & & & & & \\
\hline $1-3$ days & 19 & 2.3 & $55(18-79)$ & $29.3(20.4-42.1)$ & $7(37 \%)$ & $4(21 \%)$ & $8(42 \%)$ \\
\hline 4-5 days & 21 & 4.5 & $58(20-86)$ & $28.4(18.4-43.6)$ & $10(48 \%)$ & $9(43 \%)$ & $2(10 \%)$ \\
\hline$>5$ days & 21 & 6.5 & $61(28-76)$ & $30.7(21.1-50.3)$ & $15(71 \%)$ & $2(10 \%)$ & $4(19 \%)$ \\
\hline$p$-value & & & 0.373 & 0.543 & 0.079 & 0.086 & 0.096 \\
\hline Control volunteers & 7 & & $45(26-57)$ & $27.1(20.8-37.2)$ & & & \\
\hline
\end{tabular}

PM mean = Post mortem mean time.

\section{Findings}

\section{Study design and results}

This study comprises of 61 male cases collected in the Department of Forensic Medicine of the University of Tampere and 7 male volunteers. The selection criteria for the autopsies have been described elsewhere [13]. None of the controls or cases was reported to has been used antibiotics. Deceased had been stored in $+4^{\circ} \mathrm{C}$ within 24 hours after death. Written consent was obtained from the volunteers.

Samples of the autopsy cases were taken from rectum and cecum. All samples were frozen immediately at $-80^{\circ} \mathrm{C}$ until further processing. On the basis of time post mortem the cases were divided into groups: $1-3$ days, 4-5 days and $>5$ days. Demographic characteristics of these groups are shown in the Table 1.

Fecal samples were weighed to be $150 \mathrm{mg}$ (wet weight). Bacterial DNA was extracted from the samples using Zymo Fecal DNA Kit (Zymo Research Corporation, Irvine, California, USA). The bacterial ratios were determined by RT-qPCR using specific primers and probes (Table 2). The primers and probes for Enterobacteriacaea and Lactobacillus sp. were designed and confirmed by using BLAST (http://www.ncbi.nlm.nih.gov/) and Ribosomal Database Project (http://rdp.cme.msu.edu/probematch/ search.jsp). Specificity and cross reactivity of the designed primers and probes were tested using bacterial cultures from clinical samples [13]. PCR assays were performed with AbiPrism 7000 HT Sequence Detection System (Taqman, AppliedBiosystems, California, USA) with Taqman Environmental MasterMix. Endogen and DNA-free water was used as a negative control.

The comparative $\mathrm{Ct}$ method $(\Delta \Delta \mathrm{Ct}, \Delta \mathrm{Ct}$ sample $\Delta \mathrm{Ct}$ reference sample) [17], was used where mean values from healthy male volunteers were calculated and used as a reference to determine bacterial relative amount in rectum samples. The differences of the $\mathrm{Ct}$ values between the bacteria and the universal bacteria measurement $(\Delta \mathrm{Ct})$ for each sample were calculated; the comparative $\mathrm{Ct}(\Delta \Delta \mathrm{Ct})$ for sample and reference samples was
Table 2 Used primers and probes

\begin{tabular}{|c|c|c|}
\hline Primer and probe & Sequence $\left(5^{\prime}-3^{\prime}\right)$ & Reference \\
\hline Bacteroides sp. & & [14] \\
\hline Forward & TGGTAGTCCACACAGTAAACGATGA & \\
\hline Reverse & CGTACTCCCCAGGTGGAATACTT & \\
\hline Probe & GTTTGCCATATACAGTAAGCGGCCAAGCG & \\
\hline
\end{tabular}

Bifidobacterium sp.

$\begin{array}{ll}\text { Forward } & \text { CGGGTGAGTAATGCGTGACC } \\ \text { Reverse } & \text { TGATAGGACGCGACCCCA } \\ \text { Probe } & \text { CTCCTGGAAACGGGTG }\end{array}$

Clostridium leptum

Forward

CCTTCCGTGCCGSAGTTA

Reverse GAATTAAACCACATACTCCACTGCTT

Probe CACAATAAGTAATCCACC

Clostridium coccoides

Forward

GACGCCGCGTGAAGGA

Reverse AGCCCCAGCCTITCACATC

Probe CGGTACCTGACTAAGAAG

Enterobactericaea

This study

$\begin{array}{ll}\text { Forward } & \text { GCGGTAGCACAGAGAGCTT } \\ \text { Reverse } & \text { GGCAGTITCCCAGACATTACTCA } \\ \text { Probe } & \text { CCGCCGCTCGTCACC }\end{array}$

Lactobacillus sp.

This study

$\begin{array}{ll}\text { Forward } & \text { GCTAGGTGTTGGAGGGTTTCC } \\ \text { Reverse } & \text { CCAGGCGGAATGCTTAATGC } \\ \text { Probe } & \text { TCAGTGCCGCAGCTAA }\end{array}$

Streptococcus sp. mainly str.

[13]

Forward CCAGCAGCCGCGGTAATA

Reverse CCTGCGCTCGCTITACG

Probe ACGCTCGGGACCTACG

Universal

[16]

Forward TGGAGCATGTGGTTTAATTCGA

Reverse TGCGGGACTTAACCCAACA

Probe CACGAGCTGACGACA[A/G]CCATGCA

${ }^{*}$ This was abbreviated as Streptococcus sp. in the text. 


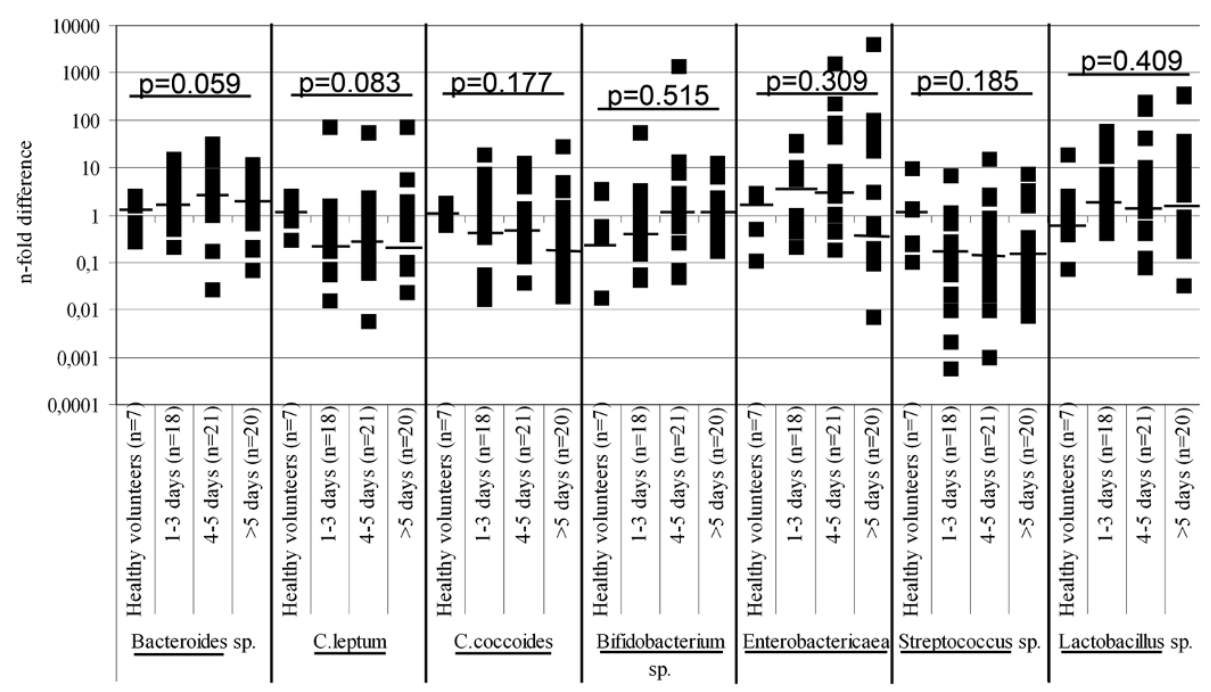

Figure 1 Relative amounts (n-fold difference) of measured bacteria (Bacteroides sp., C. leptum, C. coccoides, Bifidobacterium sp., Enterobactericaea, Streptococcus sp. and Lactobacillus sp.) in fecal samples of controls and rectum of autopsy cases. Individual values are presented as boxes, median values with horizontal lines. Comparisons over the groups were calculated using non-parametric Kruskal-Wallis test.

calculated. To determine relative amounts of bacteria in cecum samples the rectal sample was used as an inner reference.

Two standard curves were used to determine the total amount of bacteria. Tenfold dilution series of between $33 \mathrm{ng} / \mathrm{ml}$ and $0.00033 \mathrm{ng} / \mathrm{ml}$ from E. coli genomic DNA (ATCC 35401-5) as well as between $10^{9}$ and $10^{5}$ colony forming units (CFU) per milliliter from $E$.coli (ATCC 25922) were applied. The amount of CFU or bacterial DNA in the sample was calculated using values from universal measurement and the equation $\mathrm{y}=$ slope $\log$ (X) + intercept [18].

Statistical analyses were performed with KruskalWallis median test with PASW Statistical Software, version 18 (SPSS Ltd, Quarry Bay, Hong Kong). If P-value was less than 0.05 (considered significant) pairwise Post Hoc comparisons using Mann-Whitney U-test were done.

Median values of different bacteria in the stool of healthy controls and in post mortem rectum samples

Table 3 The relative amounts ( $\mathrm{n}$-fold difference) of measured bacteria in cecum samples compared to rectum samples over post mortem time

\begin{tabular}{|c|c|c|c|c|c|c|c|c|}
\hline \multirow{4}{*}{ All } & \multirow{4}{*}{$\begin{array}{l}\text { Median } \\
\text { 25th-75th }\end{array}$} & \multicolumn{6}{|l|}{ Bacterial Group } & \multirow{4}{*}{$\begin{array}{l}\text { Lactobacillus sp. } \\
0.82 \\
0.25-3.61\end{array}$} \\
\hline & & \multirow{3}{*}{$\begin{array}{l}\text { Bacteroides sp. } \\
0.32 \\
0.13-1.06\end{array}$} & \multirow{3}{*}{$\begin{array}{l}\text { C. leptum } \\
0.72 \\
0.41-1.61\end{array}$} & \multirow{3}{*}{$\begin{array}{l}\text { C. coccoides } \\
1.29 \\
0.27-3.94\end{array}$} & \multirow{3}{*}{$\begin{array}{l}\text { Bifidobacterium sp. } \\
1.18 \\
0.52-2.66\end{array}$} & \multirow{3}{*}{$\begin{array}{l}\text { Enterobactericaea } \\
0.86 \\
0.09-3.38\end{array}$} & \multirow{3}{*}{$\begin{array}{l}\text { Streptococcus sp. } \\
2.19 \\
0.52-7.50\end{array}$} & \\
\hline & & & & & & & & \\
\hline & & & & & & & & \\
\hline \multicolumn{9}{|c|}{$1-3$ days } \\
\hline & Median & 0.15 & 0.59 & 0.64 & 2.03 & 1.37 & 3.56 & 1.25 \\
\hline & 25th-75th & $0.01-0.43$ & $0.31-2.94$ & $0.20-4.55$ & $0.84-35.63$ & $0.26-14.77$ & $0.85-35.32$ & $0.46-7.11$ \\
\hline \multicolumn{9}{|c|}{ 4-5 days } \\
\hline & Median & 0.53 & 1.09 & 1.27 & 0.61 & 0.68 & 2.28 & 0.30 \\
\hline & 25th-75th & $0.17-1.60$ & $0.60-1.81$ & $0.15-2.30$ & $0.26-2.34$ & $0.03-1.85$ & $0.34-8.07$ & $0.16-1.95$ \\
\hline \multicolumn{9}{|c|}{$>5$ days } \\
\hline & Median & 0.53 & 0.60 & 2.81 & 1.03 & 0.86 & 1.85 & 1.09 \\
\hline & 25th-75th & $0.21-1.45$ & $0.41-1.39$ & $0.59-4.27$ & $0.45-1.61$ & $0.16-7.94$ & $0.27-5.68$ & $0.65-7.84$ \\
\hline & $p$-value & 0.014 & 0.472 & 0.421 & 0.054 & 0.358 & 0.192 & 0.024 \\
\hline
\end{tabular}

Results are presented as median and $25^{\text {th }}-75^{\text {th }}$ interquartile range. Non-parametric median, Kruskal-Wallis-test comparisons between groups. 
Table 4 The total amount of bacterial DNA in fecal samples

\begin{tabular}{|c|c|c|c|c|c|c|c|}
\hline & & & $\mathrm{N}$ & ng/g median* & $25^{\text {th }}-75^{\text {th }}$ & p-value ${ }^{1)}$ & p-value ${ }^{2)}$ \\
\hline Healthy volunteers & Stool & Control & 7 & 26 & $9.2-36.7$ & & \\
\hline \multirow[t]{3}{*}{ Autopsy cases } & Rectum & 1-3 days & 18 & 8 & $2.0-53.6$ & & \\
\hline & & 4-5 days & 21 & 8 & $1.7-41.4$ & & \\
\hline & & $>5$ days & 20 & 42 & $12.0-124.2$ & 0.044 & 0.023 \\
\hline \multirow[t]{3}{*}{ Autopsy cases } & Cecum & 1-3 days & 19 & 51 & $13-3-94.1$ & & \\
\hline & & 4-5 days & 21 & 68 & $5.1-194.7$ & & \\
\hline & & $>5$ days & 21 & 48 & 6.5-113.6 & & 0.982 \\
\hline
\end{tabular}

${ }^{*} 1 \mathrm{ng} / \mathrm{g}$ corresponds to $4.8 \times 10^{10}$ colony forming units using E. coli as a standard. P-values (over the groups) for ${ }^{1)}$ healthy volunteers and autopsy cases, 2) autopsy cases only.

$25^{\text {th }}-75^{\text {th }}$ interquartile range. Non-parametric median, Kruskal-Wallis-test comparisons over the groups.

showed no statistically significant changes over post mortem time (Figure 1). In cecum, significant post mortem time-dependent differences were observed over the groups in the relative amounts of Bacteroides sp. $(\mathrm{p}=0.014)$ and Lactobacillus sp. $(\mathrm{p}=0.024$, Table 3$)$. There were significantly more Bacteroides sp. $(\mathrm{p}=0.012)$ and less Lactobacillus sp. ( $\mathrm{p}=0.015)$ already in $4-5$ days. Statistically significant differences in the total amount of bacterial DNA were seen in healthy volunteers and autopsy rectum samples $(\mathrm{p}=0.044$, Table 4$)$. In autopsy rectum, the amount of bacterial DNA remained quite stable with time elapsing post mortem except for a high increase observed after day 5 post mortem $(\mathrm{p}=0.023)$. A slightly higher total amount of bacterial DNA (measured as a wet weight) in stool samples donated by the volunteers compared to autopsy rectum samples might be due to lower water concentration in stool compared to rectum without changes in bacterial ratios [19]. Inter-individual variation was great at all time points and in all bacterial measurements.

\section{Conclusion}

This study showed that relative amounts of major intestinal bacteria in rectum of autopsy cases were similar to stool donated by volunteers and remained quite stable over post mortem time up to 5 days, after which the total amount of bacteria started to increase. In contrast, in cecum significant post mortem time-dependent differences were observed as increase in ratio of strictly anaerobic Bacteroides sp. and decrease of facultative Lactobacillus sp. due to hypoxia after death. In cecum there is accumulation of undigested nutrients and metabolites produced by bacteria after death, which may be conducive to anaerobic bacterial growth. This study showed that autopsy rectum samples can be used to evaluate major intestinal bacterial populations concerning lifetime up to 5 days after death.

\section{Competing interests}

The authors declare that they have no competing interests.

\section{Authors' contributions}

ST performed experiments and analyses, helped in collection of the autopsy samples and wrote the manuscript. PK was the iniator of the project and group leader and participated in writing the script. TP was the guarantor of the microbiological part of the study, designed the sample collection and experiments, and participated in writing the manuscript. All authors read and approved the final manuscript.

\section{Acknowledgements}

The excellent technical assistance from the personnel of the Department of Forensic Medicine, especially Mervi Seppänen, Kari Mänttäri and Olli Penttilä, University of Tampere, Finland is gratefully acknowledged. We also appreciate the participation of the volunteers.

\section{Funding}

This study was financially supported by the Tampere Graduate Program in Biomedicine and Biotechnology (TGPBB), the Finnish Foundation for Alcohol Studies, the Competitive Research Funding of the Pirkanmaa Hospital District, the European Union 7th Framework Program grant number 201668 for the AtheroRemo Project, the Pirkanmaa Regional Fund of the Finnish Cultural Foundation.

Received: 30 August 2013 Accepted: 20 November 2013 Published: 25 November 2013

\section{References}

1. Peterson J, Garges S, Giovanni M, Mclnnes P, Wang L, Schloss JA, Bonazzi V, McEwen JE, Wetterstrand KA, Deal C, Baker CC, Di Francesco V, Howcroft TK, Karp RW, Lunsford RD, Wellington CR, Belachew T, Wright M, Giblin C, David H, Mills M, Salomon R, Mullins C, Akolkar B, Begg L, Davis C, Grandison L, Humble M, Khalsa J, Little AR, et al: The NIH human microbiome project. Genome Res 2009, 19:2317-2323.

2. Hayashi H, Takahashi R, Nishi T, Sakamoto M, Benno Y: Molecular analysis of jejunal, ileal, caecal and recto-sigmoidal human colonic microbiota using $16 \mathrm{~S}$ rRNA gene libraries and terminal restriction fragment length polymorphism. J Med Microbiol 2005, 54:1093-1101.

3. Morris JA, Harrison LM, Biswas J, Telford DR: Transient bacteraemia: a possible cause of sudden life threatening events. Med Hypotheses 2007, 69:1032-1039.

4. Chen Y, Yang F, Lu H, Wang B, Chen Y, Lei D, Wang Y, Zhu B, Li L: Characterization of fecal microbial communities in patients with liver cirrhosis. Hepatology 2011, 54:562-572.

5. Rosenfeld ME, Campbell LA: Pathogens and atherosclerosis: Update on the potential contribution of multiple infectious organisms to the pathogenesis of atherosclerosis. Thromb Haemost 2011, 106:858-867.

6. Eckburg PB, Bik EM, Bernstein CN, Purdom E, Dethlefsen L, Sargent M, Gill $\mathrm{SR}$, Nelson KE, Relman D: Diversity of the human intestinal microbial flora. Science 2005, 308:1635-1638.

7. Durbán A, Abellán JJ, Jiménez-Hernández N, Ponce M, Ponce J, Sala T, D'Auria G, Latorre A, Moya A: Assessing gut microbial diversity from feces and rectal mucosa. Microb Ecol 2011, 61:123-133. 
8. Mariat D, Firmesse O, Levenez F, Guimarăes V, Sokol H, Doré J, Corthier G, Furet JP: The Firmicutes/Bacteroidetes ratio of the human microbiota changes with age. BMC Microbiol 2009, 9:123.

9. Lay C, Sutren M, Rochet V, Saunier K, Dore J, Rigottier-Gois L: Design and validation of $16 \mathrm{~S}$ rRNA probes to enumerate members of the clostridium leptum subgroup in human faecal microbiota. Environ Microbiol 2005, 7:933-946.

10. Orrhage $\mathrm{K}$, Nord CE: Bifidobacteria and lactobacilli in human health. Drugs Exp Clin Res 2000, 26:95-111.

11. Turnbaugh PJ, Hamady M, Yatsunenko T, Cantarel BL, Duncan A, Ley RE, Sogin ML, Jones WJ, Roe BA, Affourtit JP, Egholm M, Henrissat B, Heath AC, Knight $\mathrm{R}$, Gordon $\mathrm{J}$ : A core gut microbiome in obese and lean twins. Nature 2009, 457:480-484.

12. Arumugam M, Raes J, Pelletier E, Le Paslier D, Yamada T, Mende DR, Fernandes GR, Tap J, Bruls T, Batto JM, Bertalan M, Borruel N, Casellas F, Fernandez L, Gautier L, Hansen T, Hattori M, Hayashi T, Kleerebezem M, Kurokawa K, Leclerc M, Levenez F, Manichanh C, Nielsen HB, Nielsen T, Pons N, Poulain J, Qin J, Sicheritz-Ponten T, Tims S, et al: Enterotypes of the human gut microbiome. Nature 2011, 12:174-180.

13. Tuomisto S, Karhunen P, Vuento R, Aittoniemi J, Pessi T: Evaluation of post mortem bacterial migration using culturing and real-time quantitative PCR. J Forensic Sci 2013, 58:910-916.

14. Brunk CF, Li J, Avaniss-Aghajani E: Analysis of specific bacteria from environmental samples using a quantitative polymerase chain reaction. Curr Issues Mol Biol 2002, 4:13-18.

15. Furet JP, Firmesse O, Gourmelon M, Bridonneau C, Tap J, Mondot S, Doré J, Corthier G: Comparative assessment of human and farm animal faecal microbiota using real-time quantitative PCR. FEMS Microbiol Ecol 2009, 68:351-362.

16. Yang S, Lin S, Kelen GD, Quinn TC, Dick JD, Gaydos CA, Rothman RE: Quantitative multiprobe PCR assay for simultaneous detection and identification to species level of bacterial pathogens. J Clin Microbiol 2002, 40:3449-3454.

17. Suzuki N, Yoshida A, Nakano Y: Quantitative analysis of multi-species oral biofilms by TaqMan real-time PCR. Clin Med Res 2005, 3:176-185.

18. Yoshida A, Suzuki N, Nakano Y, Kawada M, Oho T, Koga T: Development of a 5' nuclease-based real-time PCR assay for quantitative detection of cariogenic dental pathogens streptococcus mutans and streptococcus sobrinus. J Clin Microbiol 2003, 41:4438-4441.

19. Geibel JP: Secretion and absorption by colonic crypts. Annu Rev Physiol 2005, 67:471-490.

doi:10.1186/1757-4749-5-35

Cite this article as: Tuomisto et al:: Time-dependent post mortem changes in the composition of intestinal bacteria using real-time quantitative PCR. Gut Pathogens 2013 5:35.

\section{Submit your next manuscript to BioMed Central and take full advantage of:}

- Convenient online submission

- Thorough peer review

- No space constraints or color figure charges

- Immediate publication on acceptance

- Inclusion in PubMed, CAS, Scopus and Google Scholar

- Research which is freely available for redistribution 